\title{
Dil Oyunları Kuramı Ne Önermektedir?
}

\author{
What Does The Language Games Theory Suggest?
}

\author{
Cenan KUVANCI ${ }^{1}$
}

Araştırma Makalesi / Research Article

Geliş Tarihi / Received: 12.01.2021

Kabul Tarihi / Accepted: 30.04 .2021

Doi: $10.48146 /$ odusobiad.858756

Atıf / Citation: Kuvancı, C., "Dil Oyunları Kuramı Ne Önermektedir?” ODÜSOBİAD 11(2), 2021, 377390, Doi: 10.48146/odusobiad.858756

\section{Öz}

Dil oyunları kuramına göre, ister bilimsel ister dinî, tüm temsil sistemleri (yani söylemler), pratik hayatın sınırları içinde gerçekleșen insanlararası uzlaşımlardan başka bir şey değildir. Bilim, din, sanat, ahlâk ... gibi alanların nesnel doğruluk ve geçerlilik kıstaslarına sahip olduğu düşüncesi terkedilmelidir. Dolaysıyla bir söylemdeki kavram ve ifadelere ilişkin akla uygunluk, anlamlılık ve doğruluk kıstaslarının bizzat sözkonusu söylemin kendi içinde aranması gerekir. Çünkü kültürel/dilsel kategorilerden bağımsız ve herhangi bir dil oyunuyla ilişskisi olmayan bir gerçeklik bulunmamaktadır. "Gerçek" kavramı, ancak herhangi bir dil oyunu bağlamında anlama sahip bir kavramdır. Bir kelime ya da kavramın anlama sahip olması için, onların delalet ettiği bir özün ya da nesnel bir karşılığın bulunması da gerekmez. Kaldı ki, bir şeyin özünü oluşturduğu iddia edilen özellikler belli bir dil oyunu içinde üretilmektedir. Sözgelimi, ahlâkta "iyi" sanatta "güzel" kelimelerine baktığımızda, bunların imâ ve işaret ettiği bir iyilik ve güzellik özünün bulunduğunu düșünme eğilimi gösteririz. Fakat dil oyunları kuramını benimseyen düșünürler bu kelimelerin bir özünün olmadığını ve ancak fiilî kullanılışlarına bakarak "semantik" sözde bir özün ortaya çıkarılabileceğini söylerler.

Anahtar Sözcükler: İslam felsefesi, dil oyunları, dil, anlam, kullanım.

\begin{abstract}
According to the language games theory, all representational systems (id est all discourses), whether scientific or religious, are nothing more than inter-human conventions that take place within the limits of practical life. The idea that the fields such as science, religion, art, and morality have objective criteria of truth and validity should be abandoned. Therefore, the criteria of rationality, meaningfulness and accuracy relating to the concepts and statements in a discourse should be sought within the discourse itself in question, because there is no reality that is independent of cultural-linguistic categories and is not related to any language game. The concept of "truth" is a concept that has meaning only in the context of any language game. So that a word and a concept have a meaning, it is not necessary to be an essence or an objective correlative to what they indicate. Moreover, the properties that are claimed to constitute the essence of something are produced within a certain language game. For example, when we look at the words "good" in morality and "beautiful" in art, we tend to think that there is an essence of goodness and beauty that those imply and indicate. However, the thinkers who adopt the language games theory say that these words have no essence and that a so-called "semantic" essence can be revealed only by looking at their actual usage.
\end{abstract}

Keywords: Islamic philosophy, language games, language, meaning, use.

\section{Giriş}

Wittgenstein`a göre, bir dil oyunu başka herhangi bir dil oyunuyla mantıksal hiçbir bağlantısı bulunmayan başlı başına bir etkinliktir. Bu bakımdan, bir dil oyunu başka herhangi bir dil oyunuyla örtüşebilen onlarla ortak anlam referansına sahip bir iddia ihtiva etmez. Bir dil oyununda ne denmek

1 Doç. Dr., Ordu Üniversitesi, İlahiyat Fakültesi, Ordu, cenankuvanci@hotmail.com, ORCID ID: 0000-0002-1175-7071 
istediğini anlamak için kelime ve cümlelerin ne zaman nerede ifade edildiklerini ve ifade ediliș amaçlarını araştırmak gerekir. Bir söylemdeki cümlelerin anlamını başka disiplinlerin kıstaslarını kullanarak belirlemek de uygun değildir. Bir kelime ve cümlenin anlamlı olmasının ölçüsü, onun kullanıldığı dil oyununun içinde aranmalıdır. Bir ifadeyi tam anlamıyla değerlendirebilmek ancak kendi dünyası içinde, yani, o ifadeyi kullanan cemaat ya da toplumun takip ettiği davranıș ve hayat tarzı içinde, orada ifa ettiği işlevi iyi anlamaktan geçer. Çünkü her dil oyunundaki ifadeler, bir oyundaki davranış ve hareketler gibi, bağlama dayalı ifadelerdir. Bir söylemdeki kavram ve ifadeler, dışarıdan yöneltilen tutarsızlık, anlaşılmazlık, irrasyonellik veya nesnel gerçekliğe uymama suçlamalarından muaftır; zira, her söylem ya da dil oyunu tutarlılık, anlaşılırlık, rasyonellik ve gerçeklik konusundaki belirleyici kıstaslarını kendisi koyar.(Wittgenstein, 1958, 142-143; Koç, 1995, 243-244)

\section{Dilsel Anlamın Oluşumunda Kullanımın Etkisi}

Wittgenstein`a göre, kelimeler farklı amaçlarla çok çeşitli şekillerde kullanılabildiğinden, bir kelimenin anlamını öğrenmek için, genel geçer bir tanım aramak yerine, onun bir dil oyununda nasıl kullanıldığına bakmak gerekir. Uygun bir benzetmeyle, sözcüklerin işlevleri bir alet kutusundaki çekiç, kerpeten, tornavida, tutkal, cetvel ... gibi şeylerin işlevleri kadar çeşitlidir. Tüm aletler bir şeyi değiştirme işini görür; çekiç çivinin, testere tahtanın şeklini değiştirir. Zihnimizi karıștıran şey, bir ifadeyi işittiğimizde veya okuduğumuzda, sözcüklerin tek biçimli olarak görünmeleridir; zira, onların kullanılış şekillerini biz ilk bakışta açık bir şekilde göremeyiz. Bu tıpkı bir lokomotife bakmaya benzer. Lokomotifte, tüm kollar el yardımıyla kullanıldığı için, onların az çok birbirine benzediğini görürüz. Ancak, bunlardan biri, bir valfin açllmasını düzenleyen, sürekli hareket ettirilebilecek manivela aletidir; diğeri, kapalı ya da açık olmak üzere sadece iki konumda kullanılabilen bir şalterdir; üçüncüsü, ne kadar sıkı çekilirse, o kadar sert fren yapmaya yarayan bir fren koludur; ve dördüncüsü, sadece öne ve arkaya hareket ettirilerek çalışan bir pompa koludur. Dolayısıyla, tüm bu kolların ne için kullanıldığının açı bir dille tanımlanması gibi, dildeki her sözcüğün hangi amaçla nerede nasıl kullanıldığı açık bir şekilde belirlenmediği müddetçe pek bir şey söylenmiş olmaz. Çünkü dildeki sözcükler de benzer görevler ifâ ederler. Tıpkı, satrançta "şah" taşının anlamının bütünüyle onun oyundaki rolü tarafından tespit ve tayin edilmesi gibi, "iyi," "doğru," "güzel," "âdil". . .vd. kelimelerin anlamları da kullanıldıkları dil oyunları tarafından belirlenir.(Wittgenstein, 1958, 67,11-12, 1978, 67)

Bu demektir ki, bir kelimenin anlamı büsbütün onun kullanıldığı bağlamla ilgilidir; çünkü onun başlı başına bir anlamı yoktur; anlam, o, ancak dilsel bir bağlamda kullanıma girdiğinde açığa çıkar. Bağlamla anlam arasında doğrudan bir tekabüliyet ya da ilişki bulunur. Olgu ve olayları olandan farklı bir şekilde tasavvur ettiğimizde, belli bazı dilsel bağlamlar önemini yitirir ve başka bağlamlar önem kazanır. Çünkü değişik anlamlar değişik bağlamlar, yani fonksiyonlar demektir. Bağlam değiștiği zaman kavramlarda da bir değişiklik olur ve kavramlara bağlı olarak kelimelerin anlamı da değişir.(Wittgenstein, 1969, 10)

Wittgenstein, "dili çeşitli caddeleri, dar sokak ve meydanları, eski evleri ve belli dönemlerde bunlara ilave edilen yeni binaları ihtiva eden ve düzenli bulvarları olan mahalleler tarafından çevrilmiş eski bir șehre benzetebiliriz" diyor.(Wittgenstein, 1958, 8) Dil, aynı anda maddî, ruhî, bireysel ve toplumsal özellikler taşır. Dolayısıyla dil, mâhiyeti itibariyle, bir veya birkaç kalıba indirgenmesi son derece güç, çok çeşitli biçimlere girebilen, gayr-i mütecanis bir şeydir.(Barthes, 1977, 13) Dil oyunlarının ne kadar çeşitli olduğunu göstermek için şunları zikredebiliriz: Emirler vermek ve onlara uymak; bir nesnenin görünümünü tasvir etmek ve ölçülerini vermek; bir tasvirden bir nesne oluşturmak; bir olayı rapor etmek; bir olay hakkında spekülasyon yapmak; bir hipotez oluşturmak ve onu test etmek; bir deney sonucunu tablo veya taslak halinde göstermek; bir hikâye kurgulamak ve onu okumak; oyun oynamak; şarkı söylemek; bilmece çözmek; şaka yapmak; pratik bir aritmetik problemi çözmek; bir dilden diğer dile çeviri yapmak; sormak, teşekkür etmek, hakaret etmek, selamlaşmak, dua etmek. . . gibi. Tüm bunlar sözcüklerle gerçekleştirilen birer dil edimidir.(Wittgenstein, 1999, 43)

Wittgenstein`a göre, tüm bu dil edimleri için bir temel bulmak isteniyorsa, onların ortaya çıtıkları linguistik-epistemik cemaatin hayat şekline bakmak gerekir. Çünkü topluluk ya da cemaat her türlü temellendirme, açıklama ve anlamanın temelini oluşturur. Kelimeler herhangi bir linguistikepistemik cemaat tarafından belli bir hayat bağlamında bilinçli bir şekilde kullanıldığında ancak 
anlam kazanır. Onlar bireyler veya bir cemaat tarafından kullanılmadıkça, neredeyse anlama sahip değildir. Çünkü kelimelerin nasıl anlaşılması gerektiği, tek başına kelimelerden çıkarılamaz. Sözgelimi, "basit" sözcüğünü, "Tanrı basittir" ve "bu soru basittir" ifadelerinde olduğu gibi, çok değişik şekillerde kullanırız; fakat onların anlamı kullanıldıkları bağlamdan bağımsız değildir. 0 halde, kelimelerin anlamı dil oyunlarına bağlı olarak değişmektedir.(Wittgenstein, 1998, 25) Öyleyse, dille ne söylendiğini anlamak istiyorsak, söylenen şeyi önceden belirlenmiş kategorik bir şemaya oturtarak anlamak yerine, onun kullanılışına bakmamız gerekir. Başka türlü söyleyecek olursak, bir sözün ne demek istediğini anlamak için, o sözün söylendiği bağlamı, onun bașka sözlerle olan bağlantısını, söylenme amacını, söyleyen kişinin muhatabından beklediği cevabl, o sözün gerekçelendirilmesi için öne sürülen nedenleri keșfetmeye çalıșmalıyız. Ayrıca antrparantez, bir ifadeyi anlamanın en iyi yolu bu ifadenin nasıl kullanıldı̆̆ını bilmek kadar, aynı zamanda bu ifadenin, ona inananların hayatları üzerinde ne tür bir etkide bulunduğunu anlamaktan geçer.(Dancy, 2006, 75-76; Koç, 1995, 239,242; Wittgenstein, 1990, 10-11)

Wittgenstein`a göre, felsefedeki patolojik durumlardan biri, dil oyunlarını rasyonel olarak temellendirmemiz gerektiği iddiasıdır. Her bir dil oyunu için metafiziksel bir temel bulmanın insanların görevi olduğu iddia edildiğinde, söylenebilecek en doğru şey, "bir dil oyununun oynandığı"dır. Wittgenstein, futbol ve basketbol gibi oyunlar için sabit bir temel bulmaya kalkışmıyorsak, farklı dil oyunları için de sabit bir temel aramamak gerekir diyor. Bu anlayışa göre, insan istese de bunu başaramaz; zira, dilsel ve zihinsel kategorilerden bağımsız bir temel gerçeğin var olduğu şüphelidir. İnsan bulunduğu yerden başlar ve eşyanın doğası ile ilgili anlayışını kültürel kategorilere dayalı olarak oluşturur. Başka bir ifadeyle, yaptığımız uslamlamanın yeri, yaşama tarzımızdır. Kendimizi içinde bulunduğumuz durumdan soyutlayamayız, zira, akıl tam bir boşlukta, tüm bağlamların dışında işlemez. Bundan dolayı, bağlam anlamın kaynağıdır; gerçeklik de kavramlarımıza bağlı olarak olușan bir şeydir. Çünkü şeyleri nasıl göreceğimizi, kökleri özel uygulamalara dayanan kavramsal çerçeveler belirler. 0 halde, gerekçelendirme, çürütme, delil, kanıt ve doğru-yanlış değerlendirmeler gibi eylemler bir dil oyunu içinde gerçekleşen şeylerdir. Bu terimler muayyen bir hayat tarzı içinde zamanla oluştukları için, her dil oyununda farklı anlama gelecek şekilde kullanılmaktadır. Amaçlı bir etkinlik olan dil oyunlarından her birinin ayrı bir grameri vardır. Bir dil oyununun grameri, tıpkı bir oyunda olduğu gibi, bir uzlaşımın ürünüdür; bu bakımdan, o, ne kadar katılımcisı varsa o kadar kendisini kabul ettirme gücüne sahip olur.(Lyotard, 2014, 2526; Magee, 2000, 342; Malcolm, 1993, 465; Trigg, 1996, 13,37)

Bundan dolayı, bir dil oyununa ilișkin olarak, her türlü değerlendirme ve eleștiriyi onun semantik sınırları içinde yapmak gerekir. Çünkü bir dil oyununa ait önerme ve ifadeleri, ondan bütünüyle farklı başka bir dil oyununun kurallarına ya da gramerine göre değerlendirmek ve eleştirmek uygun değildir.(Barret, 1991, 119) Her dil oyunu, ancak kendi derin gramerine göre anlaşılabilir. Her kültür birbirinden büsbütün ayrı birer bağlam oluşturduğu için, her birinin derin grameri de farklıdır.(Wittgenstein, 1970, 8-9) Dolayısıyla, bir ifadeyi, ancak belli bir toplumsal bütün içinde gerçekleșen dil kullanım șekline dayalı olarak doğru bir șekilde anlayabiliriz. Açıç̧a, dil, onu kullanan bireylerin alışkanlıkları göz önünde bulundurularak kavranabilecek toplumsal bir olgudur. Zaten belli bir toplum da kendisini diğerlerinden, kendini organize ettiği araçlarla ayırır ve bu araçların en ayırt edici olanı da dildir. Bir toplumun dili, oluş halindeki hayat süreçlerinin bir parçasıdır ve kolektif hafızayı oluşturur. Çünkü dil geleneksel davranış kalıplarının ve uygulamaların sözel ifadesidir. Sözkonusu davranış kalıpları ve uygulamalar dilsel anlamın kaynağıdır.(Janik \& Toulmin, 2008, 142143) Zira, her dil oyunundaki kavramlar ve akıl yürütme şekilleri belli bir yere kadar nev`i şahsına münhasırdır (sui generis). Filozofun görevi bu mantığı anlamak ve bu mantığın kurulduğu yaşama biçimini açığa çıkarmaktır.(Kerr, 1997, 30; Nielson, 1982, 68)

Yașam biçimi, toplumsal varlıklar olarak insanların birbirleriyle ortaklașa sahip oldukları dilsel ya da dilsel olmayan davranışlar, önkabuller, pratikler, gelenekler ve kullandıkları dilde şekillenen anlayışlarla ilgili genel kabul gören uzlaşımlardır. Dil, insanların karakteri ve yaptıkları sayesinde tarihsel süreç içinde oluşur ve anlam da, bir dili kullananların ortak kabulleri ve tutumlarına dayalı olarak dilsel ifadelerde üretilir. Sözgelimi, dilin kendisine dayandığı hayat şekli, dilin kullanımını meydana getiren pratiklerin temelini oluşturduğundan, düşünme ve konuşmada kullanılan kavramlar hakkında nihaî açıklama ve doğrulama talepleri son bulmalıdır. Onları, ideal olarak görülen başka bir söyleme indirgeyerek tahrip etmek ya da (meta) üst bir dile dayalı olarak yorumlamak doğru değildir. Çünkü yaşam biçiminin ötesinde bir meşruiyet zemini 
bulunmamaktadır. Her türlü bilișsel iddianın atıf çerçevesi belli bir hayat tarzıdır. Bir dili öğrenmek, ifadelerin anlamlarını kendisinden aldığı yaşam biçimini, önkabulleri ve uygulamaları öğrenmek demektir. Bu nedenle, ne metafiziksel açılamaya ne de haklılaștırmaya gerek vardır.(Grayling, 2008, 124-125)

Bu durumda yapılacak en uygun iş, dikkati dilin hangi amaçla nasıl kullanıldığına yöneltmek olacaktır. Bir kimse dilsel bir bildirimde bulunduğunda, kelime ve cümlelerle bir iş yapmış olur. Bu iş bir dil oyunu içinde özgül kullanım bağlamında gerçekleșir. Buna göre, "yabancı bir toplum," sahip olduğumuz gramatik kurallara dayalı olarak anlayamadığımız toplumdur. İki toplum arasında insan kavrayışını aşan bir durum olduğu için değil, köklü gramatik farklılıklar bulunduğu için onu anlamakta zorlanırız. İnsanları ve toplumları birbirinden ayıran, aslında, söylem farklarından oluşan kıyaslanamazlık durumudur.

\section{Kapalı Dil: Bir Gerçekdıșıcılık}

Burada "kapalılık"la kastedilen șey, kavrayıș tarzımızın bütünüyle bir dil oyununun hususî bağlamında şekillendiği ve bu çerçeveyi aşamadığı; yani, insanın tüm entelektüel ürünlerinin nihai olarak kültürel-dilbilimsel hayat biçimleri tarafından üretildiği ve onlarla sınırlı olduğudur. İnsan bilgisi, farklı hermenötik tavırlara sahip epistemik cemaatlerin kültürlerüstü bağımsız bir gerçeklikle yakın bir ilişki içinde bulunması gerekmeyen dilsel ve toplumsal pratiklerine bağımlı bir üründür. İnsan tecrübesi, daha baştan dilsel olarak yapılandırıldığı ve çeşitli dil yapıları, ispat edilebilecekleri bağımsız bir gerçeklikle irtibat içinde bulunmadıkları için, insan zihni, kendi mahalli hayat tarzı içinde şekillenen dilsel "gerçekliğin" dışında bir gerçekliğe vakıf olma ve nüfuz edebilme iddiasında asla bulunamaz.(Tarnas, 2012, 252)

Kavrayışımızın, parçası olduğumuz epistemik topluluk tarafından biçimlendirildiği iddia edildiğinde, başka bir kültür ya da toplumda yaşayan insanların dillerini anlayamama gibi üstesinden gelinmesi zor bir problemle karşı karşıya kalırız. Kültürlerüstü bir gerçeğe atıfta bulunmadığımız müddetçe, belli bir zaman ve mekânın varsayım ve önyargılarının büsbütün tutsağı oluruz; çeşitli anlam ve varsayımlar hakkında nihai bir karar verilemez ve bunlardan hangisinin doğru ve gerçek olduğu tespit edilemez; hakikati temsil etme konusundaki beşeri çabaların hangi temel gerçekliğe göre belirlendiği söylenemez. Çünkü anlamı belirleyen bağlamlar hiçbir zaman sabit olmadığı ve metnin diş yüzeyinin gerisinde görünüște tutarlı, fakat aslında birbiriyle bağdaşmayan bir anlam çokluğu bulunduğu için, dilsel anlam gerçekten istikrarsızdır.(Tarnas, 2012, 252-253) Fakat anlamın istikrarlı olması için onun tüm bakış açılarına aşkın değişmez bir "gerçeklik"le bağlantılı olması gerekmektedir. Oysa, dil oyunları, gerçekliği münhasıran belli bir bakış açısına dayandırdığı için, bir bakış açısından görülen şeyle başka bir bakış açısından görülen șey birbiriyle kıyaslanamayacak kadar farklı olmaktadır. Durum böyle olunca, bir gelenek ya da toplumda algılanan şeyle diğer gelenek ya da toplumda algılanan şey arasında bize dayanak teşkil edecek bir benzerlik ilişkisi kurmak imkânsızlaşır. Çünkü iddialarımız için ortak bir atıf çerçevesi, paylaşabileceğimiz bir deneyim, ve hatta değişmez ortak bir "insanî öz" bile bulunmamaktadır.(Trigg, 1996, 63-64)

Durum böyle olduğunda, bir kelime, ifade ya da tabir ile belli bir durum, olay ya da olgu arasında ilişki kurmaya kalkıştığımızda, "gerçek" bir ilişkinin olmadığını, fakat bizim bir dil oyunu içinde onu oluşturduğumuzu görürüz. Bu ilişki kapalı bir söylem içinde belli bir bağlama dayalı olarak kurulur. Çünkü, gerçek, dilin nasıl kullanılması gerektiğini insana telkin etmez. Dilin kullanılış şekli, belli bir pragmatik anlayışa dayanır. Başka bir ifadeyle, dile ilişkin anlayış tarzları müşahhas kullanımın kaynağı olmakla birlikte, yeri geldiğinde müşahhas kullanım dil anlayıșlarını belirlemektedir.(McGinn, 2005, 89) Dolayısıyla, dilin kullanımına ilişkin bir kurala uymak bir pratiğe uymaktır; yani, belli bir tecrübe bağlamında kabul görecek şekilde dili istihdam etmek ve davranmaktır.

Bu yaklaşıma göre, her söylem bütünüyle kendi düzenleyici ilkeleri tarafından yönlendirilmektedir. Bundan dolayı, bir dil oyununun kapalı ve sadece kendi kullanım alanında iş gören ve tam da bu nedenle, başka hayat şekilleri içinde oluşan dil oyunlarıyla mukayese edilemez ve iletişimde bulunmaya yeteneksiz olduğu düşünülmektedir. Bu, insan tecrübesinin bütünlüğü açısından pek çok olumsuz içerim ve uzantıları olan bir çözülmedir; zira, her şeyi kuşatan metafizik birliğin ya da hakikatin yerine, her biri kendi kıstas veya ilkeleri tarafından yönlendirilen ve kendi diliyle konuşan lokal doğruluklar geçmektedir. Başka bir ifadeyle, burada her biri birbirinden kopuk küçük dünyalar dizisi ikâme edilmektedir. Neticede, tüm bilişsel süreçleri dilin kullanımına dayalı olarak 
tanımlamanın, bir tarafın çok fazla anlam atfettiği bir şeye, diğer tarafın hiç anlam atfetmemesi sonucunu doğurduğunu söyleyebiliriz.

Bu noktada, Tanrı̀nın varlığını kabul eden teistler ile reddeden ateistler arasında bir karşılaştırma yapmak uygun olacaktır. Denebilir ki, Tanrı̀nın varlığını kabul eden bir teist, doğal fenomenleri açıklamada belli roller üstlenen açıklayıcı doğaüstü varlıkların bulunduğuna 'kesin olarak inanan' biridir. Teistler, dil yoluyla (doğa ve doğaüstü şeklinde) iki büyük ontolojik alana bölünmüş bir âlem anlayışını tevârüs etmişlerdir. Onlar âlemden bahsederken, kaçınılmaz olarak İlahî olana atıfta bulunurlar. Teistik yaklaşımda, var olan her şey Tanrı ya ilişkin bildirim ve belirtidir; yani, O`ndan haber verir. Onlara göre, âlem Tanrı̀nı ilim ve yaratma eyleminin neticesi olduğu için derindir. Âlemde gözlemlenebilir hâdiselerin maksadı bizim kolayca görebileceğimiz şekilde yüzeye yakın değil, hatta çokluk havsalamızın ötesindedir.(Acar, 2013, 69) Vuku bulan her şey, Tanrı̀nın yaratıkları içindeki etkinliği hakkında bize bir şeyler söyler. Teistler ateistlerle bir araya geldiklerinde, onların doğal olgu ve olayların vukuunu bilimsel olarak gerçekten gayet iyi bir şekilde tahmin ve kontrol ettiklerini kabul etseler de, olup bitenin ne olduğundan bihaber insanlar olduklarını iddia ederler. Ateistler ise, teistleri dillerinde çok sayıda gereksiz kelime bulunan kişiler olarak görürler. Onlar, doğal olgu ve olayları anlamanın bir Tanrının bulunup bulunmamasıyla hiçbir ilgisinin olmadığını iddia ederler. Coşkulu bir ateist, vahye inanan bir teiste 'varolan her șey gerçekte bu...' der ve teist de ona, "insanın yerde ve gökte bundan çok daha fazla șeyin var olduğunu" anlaması gerektiğini söyleyerek cevap verir. Her iki tarafın filozofları istedikleri kadar anlam analizi yapabilirler, fakat tüm bu analizler yönlendirici ve indirgeyicidir ya da alternatif hayat tarzlarını daha doğru bir şeye ulaştıramayacak kadar tasvir edicidir.(Chittick \& Murata, 2000, 114,116; Rorty, 1979, 88-89)

Açıkça anlaşılacağı üzere, her bir dil oyunu burada kapalı bir düşünce sistemi olarak görünmektedir. Dışarıya kapalı bir anlayış için her şey egemen kategorilere göre düzenlenerek açıklanır. Beklenmedik veya farklı hiçbir şey onun dünyayı düzenleme biçimine meydan okumak veya bu biçimi tahrif etmek için çizdiği tabloya müdahale edemez. Bu kontrol ve güvenlik, her şeyin belli bir dil oyunu çerçevesinde tekrar ettiği, işleyişi bozmak amacıyla yeni hiçbir şeyin araya giremeyeceği fasit bir daireye bir tür kapatılmışlık duygusu (claustrophoby) pahasına elde edilir. Dahası, bu düşünme biçimi artık farklı düşünme biçimlerine kapıyı tamamen kapatan, yalnızca başlama noktasını doğrulayan ve dışarıdan yapılacak eleștiri ve sorgulamadan kendini muaf gören bir dogmatizme gömülen bir anlayışa dönüșmektedir.(Falzon, 2001, 30-31) Daha da ilerde, dilin belli bir kullanımına dayanan kapalı düşünme biçimleri dinî fundamentalizm veya siyasî fanatizm şeklinde de somutlaşabilir. Bu tür yönelimler, düşünce ve davranış için, kendi içinde bütüncül, fakat tecrübenin bütünü düşünüldüğünde son derece sınırlı bir ufuk sunarlar. Bunlar, 'hakikat'e sahip olmayı güvence altına alırlar; fakat temel özellikleri itibariyle eleştiriye kapalı, dogmatik ve değişime dirençlidirler. Olgu ve olaylar onların yönlendirici kategorilerine göre yorumlanır ve onlar yalnızca bu kategorileri doğrulamaya yararlar. Belli bir dil oyunu çerçevesinde gerçekleşen kapalı düşünme biçimlerini paylaşan insanlar, kendi inanç sistemlerine karşı olan ve onun dışında kalan fikir ve inançları kabul etmeyi reddetmektedirler. Bu durumun, tedavisi imkânsız zihinsel bir miyopluğa yol açtığını söylemek bile mümkündür.

Burada dile getirmeye çalıştığımız itiraz, belli bir dil oyunu pratiğinin insan varoluşunun bütününü içine alabilecek güçte olmadığını söylemektir. Sözgelimi, teistik bir dinî inanca sahip bir insanın pratikleri, bir dil oyunu bağlamında sadece belli temel inançlara sahip olmasıyla izâh edilemez. Sözkonusu insanda duygu, düşünce, tutum ve tecrübeler bir bütün oluşturur. İnanan insanın inanmayan insandan farklı davranması beklenir. 0, davranışlar yoluyla inandığı dinin ilke ve kurallarını takip etmeye çalışır. Bu davranışlar anlam ve önemini bütünüyle gerçekleştirildikleri beșerî (yani psiko-sosyal) bağlamlardan almaz. Dinin topyekûn psiko-sosyal bir olgu olarak anlaşılması, onun içinin boşalmasına, güvenilirlik, doğruluk ve nihai anlam gibi birçok özelliğini ve hatta bireysel ve toplumsal anlam ve önemini kaybetmesine neden olur. 0 halde, dini salt toplumsaldilsel bir görüngüye indirgemek doğru olmadığı gibi, onu bilişsel boyuttan yoksun görmek de doğru değildir. Çünkü temel dinî hakikat iddialarını dile getiren önermelerin tutarlılı̆̆ı, onların mantıksal olarak zorunlu bir ifade olmaları kadar, nesnel ifade olmalarından da gelir. Çünkü dinî ifadeler, hayatımıza nasıl bir yön vermemiz ve olaylar karşısında ne tür bir tavır takınmamız gerektiği konusuyla ilgili olduğu kadar, hatta bundan daha da ileride, "gerçeğin" ne olduğu konusuyla da 
ilgilidir. Bu nedenle, dinin varoluşsal ve fenomenal yönü, aşkın ve nesnel öğretisel yönüyle birlikte değerlendirilmelidir.

Öyle anlaşılıyor ki, psiko-sosyal dilsel perspektife yaptıkları vurgu, dil oyunu kuramını benimseyen düşünürleri hakikat kavram ve olgusundan uzaklaștırmıștır. Zira, bu perspektifte, hakikat ve doğruluğa ilişkin kıstaslar ne Tanrı tarafından belirlenmekte ne de doğa düzeninde bulunmaktadır. Bunlar tamamen insan ürünüdür. Bu oldukça sofistike bir çeşit rölativizmdir; zira, bu anlayışa göre, gerçeği belirleyen dilsel pratiğin dışında herhangi bir şeyin bulunup bulunmadığının bir önemi yoktur. İnsanla ilgili her konuda belirleyici olan șey belli bir söylemdir ve dile dayanan ve dili mümkün kılan yaşama biçimleridir. Genel dildeki sözcükler anlamlarını, onların kullanım koşullarına bağlı olarak toplumsal bağlamdan alırlar. Bu koşullar sadece onların anlamını belirlemez, referanslarını da belirler. Dil hiçbir şekilde gerçeğe yönelmez, bunun yerine, sûnî bir oyuna dönüşür. Doğru olan, doğru görünen şeydir. Bu yüzden, artık doğru hakkında konuşulamaz;(Scruton, 1981, 280-282) ancak yaşam biçimleri ve dilin kullanım bağlamları hakkında konuşulabilir. Çünkü bu yaklaşıma göre, kullanımı referans belirlemez, referansı kullanım belirler. Bu da tasavvur ile gerçeği birbirine karıștırmak gibi absürd bir durumdan başka bir şey değildir.

\section{Açık Dil Mümkün Müdür?}

İslâm entelektüel geleneğinde, varlığın farklı düzey ve mertebelerinin olduğu ve buna bağlı olarak farklı söylemlerin (yani, felsefî teolojik sistemlerin) bulunduğu iddia edilmiştir. Hem deney ve gözlem, hem mantıksal analitik araçlarla yapılan soruşturmalar, hem keşf ve müşahedeler, hem de kutlu kitabın bildirdikleri, üslup farklılıkları olmakla birlikte, varlığa bakmanın birer yoludur. Varlık bilinebilir, ancak doğru ve uygun araçlarla çalışmak kaydıyla. Elbette fertler varlıkla bağlantı kurma kabiliyetleri bakımından birbirinden farklıdır. Bilindiği gibi, bilgide iki kutup vardır: Bilginin öznel kutbu olan bilen insan (süje) ve nesnel kutbu olan kâinât, yani (obje). Öznel kutup, insanda hiyerarşik olarak bulunan tüm bilme güç ve kabiliyetlerinden oluşur. Başka bir ifadeyle, insan birden çok bilinç düzeyine sahip olabilecek özelliktedir. Bilgide nesnel kutup olan kâinât, yani, bilinen obje de hiyerarşik yapıdadır. Daha açık bir ifadeyle, kâinât birçok varlık düzeyine sahiptir. Dolayısıyla, bilgi yöntemi, insanın bilgi elde etme melekeleri ile kâinâtın hiyerarșisi arasındaki ilișkiyle ve bu ilișkiyi yöneten prensiplerle irtibatlıdır. Bu yüzden tek bir söylem ya da dil oyunu yerine entelektüel derinlikleri, boyutları ve kesinlikleri birbirinden farklı yollar mümkündür. İnsanın bilme faaliyetlerinin dinamiklerini kavramsallaştırmada kullanılan detaylı terminoloji ve tasvirler, bir ekolden diğerine değişebilir. Her bir söylem aynı gerçekliğin farklı cephelerini değişik perspektiflerden farklı amaçlarla vurgulayarak onlara temas eder.(Bakar, 2012, 33-34) Çünkü bilgi oluşum süreçlerinde öznel kutup ile nesnel kutup arasındaki ilişki tek bir tarzla sınırlı değildir; tek algılama ya da farkında olma şekli yoktur.

Bilgi elde etmede, kimi deney ve gözlemi, kimi salt analitik-aklî vasıtaları, kimi de mistik yolu kullanır. Fakat bu yollara dayalı olarak kurulan söylemlerden birini diğeri adına yok saymak yerine, bunları birbirini tamamlayan mütemmim cüzler olarak görmek daha uygundur. Çünkü bir söylem ya da dil oyunu bir varlık düzey ve mertebesi hakkında muayyen kavramsal ya da imajinatif araçlarla bilgi verirken, aynı zamanda, farklı söylem türleri arasında aracılık da edebilir. Sözgelimi, hayalî söylem ya da dil oyununda kullanılan kavramlar, hem düşünülür hem de maddî/duyulur dünyanın özelliklerine sahiptir. Bu kavramlar sayesinde maddî varlık ve söylem alanından aklî varlık ve söylem alanına geçiş gerçekleșir. Belli bir seviyedeki söylemde üretilen bilgiden başka üst bir söylem ve bilgi düzeyine geçiş mümkün olmazsa, bilişsel bir gelişimden bahsedilemez. Bilişsel güç ve yetiler arasında bir hiyerarşi olduğu gibi, bilgide de vardır. Doğrusu, belli bir söylem içinde kalarak üst seviyede bir gerçeği tasvir ve tavsif eden bilgi üretebiliyoruz. Bu bilgi, gerçeği olduğu gibi ifade edemese de onun nasıl olduğuna dair bir doğruyu temsil edebilir.

Bu bağlamda, temsilî dil yaklaşımını anmak uygun olacaktır. Nitekim, uygun ve etkin bir hatırlatıcı olan temsilî dil belli bir seviyedeki (İlahi âlemdeki) hakikatin, başka bir seviyedeki (fizikî âlemdeki) ona tekabül eden başka bir hakikat ile temsil edilmesidir. Temsil, dilin biçimsel yönünden ziyade içeriğini öne alan bir düşünme șeklidir. 0 , hâricî benimizi oluşturan fizikî ya da psikolojik unsurlar tarafından tamamen belirlenen (Wittgenstein `ın iddia ettiği gibi) bir dil değil; ilahî gerçekleri anlatan, fizikötesi alana açık dildir. Bu dil mevcut âlemler (aşkın ve içkin), varoluş halleri (eşyanın bu âlemdeki durumu ve așkın âlemdeki hakikî șekli) ve kelimelerin mânâ seviyeleri (zahirî ya da bâtınî mânâları) arasındaki uyumun benzetme yolu ile ortaya konulması için ihdas edilmiştir.(Livingston, 
1998, 110-111) Temsilî dil kuramı, birbirinden büsbütün farklı olan iki varlıktan birine uygulanan terimlerin, aynen değil, ama temsilî olarak, öteki varlıkla da ilgisi olacak şekilde kullanılabileceğini savunmaktadır.(Koç, 2018, 23) Sıradan günlük bilinç düzeyini esas alan dil, temsilî dilin aktardığı mânâları aktarmakta yetersiz kalmaktadır. Doğrusu, gerçeğin sadece bir mertebesine atıfta bulunan ve diğerlerine kapalı bir dilin, onun epey bir kısmına işaret etmekte yetersiz kalacağı açıkça ortadadır.

Bu yüzden, yakaladıkları hakikatleri ifade etmek için, Gazzalî(Gazzalî, 1964, 77) ve Mevlâna(Mevlânâ, 2000, 177) gibi büyük düşünürler zâhirî ve bâtınî olmak üzere, gerek söylem, gerek aklî ya da imajinatif olmaları dolayısıyla birbirinden az çok farklı iki dil kullanmaktadırlar. İslam kültür ve düşüncesi böyle bir farklılığın her zaman sonuna kadar farkında olmuştur. Burada, zâhirî dil genel olarak tüm insanların, özel olarak fakîh ve mütekellimlerin kullandığı dildir. Bâtınî dil ise, temsil ve işaret dili olup, mutasavvıflar bu dil ile salt beșerî durumların ötesindeki kapalı mânâ ve incelikleri ifade ederler ve gerektiğinde bu dile sığınırlar. Bunun nedeni, ya herkesin kullandığı dilin ifade etmek istedikleri mânâları ve hissettikleri zevk ve vecdleri dile getirmedeki yetersizliği ya da ehil olmayan kimselerden söylemek istedikleri şeyleri kapalı tutmak istemeleridir. Çünkü mutasavvıfların temsilî olarak ifade etmek istedikleri şeyler, psiko-sosyal bağlamları aştı̆̆ı için gidimli ve çözümleyici aklın tek başına kavrayabileceği şeyler değildir. Bu hakikatler "akl"ın sınırının dışında, "mâkûlat"ın ötesindedir. Ama zâhir ve bâtın dili (söylemleri), birbirine kapalı, birine dayanarak diğerinin eleştirilemeyeceği ya da desteklenemeyeceği dil oyunları değildir; aksine onlar birbirlerine açıktırlar. Nitekim, bunların her biri aynı Hakikati ayrı araçlarla yakalamaya çalışmaktadır.

Antrparantez dünya görüşünün ya da hayat şeklinin aşırı derecede tutucu, tamamen akılcı ya da maddeci olmaya zorladığı herhangi bir kişi, vecd ve istiğrak halinde yaşanan tecrübeleri kabul etmeme eğilimi göstermektedir. Böyle bir hayat șekli, kişiyi, kendi sıradan bilinç düzeyini aşan deneyimlerini bir tür delilik, kontrolün tamamen kaybı ve akla uygun olmayan duyguların akını olarak görmeye yönlendirmektedir. Zira, sözkonusu dil düzeyi, bu tür tecrübelerin tavsif ve tasviri için yeterli değildir; dolayısıyla onların reddedilmesinin sebebi, çoğu defa bu durumdur. Bir dil oyunu ya da söylemde anlamlandırılamıyor diye gerçekliğin bazı yönlerini yok saymak pek de mantıklı değildir. Bir varlık düzeyini ve söylem pratiğini esas alarak diğerini reddetmek Müslüman Bilginlerin pek tercih ettiği bir seçenek olmamıştır.

Herhangi bir ifadenin anlamının, parçası olduğu dil oyunu içinde icrâ ettiği role bakarak araştırılabileceği görüşünde elbette bir doğruluk payı vardır. Fakat, anlamlı her ifade, ifade edenin iştirak ettiği bir dil oyununun olsa olsa nisbî bir sonucudur. Din için de durum aynıdır. Sözgelimi, "Tanrı," "yaratma," "hesap günü" gibi kavramlar, bir yerde onların kullanılış biçimlerine ya da uygulamaya konuldukları yaşam tarzına atıfla anlaşılabilir. Bu yüzden, bir ifadenin uygulamada ne anlama geldiğini ortaya koymak, onu gerekçelendirmenin sadece ilk adımı olarak görülmelidir, son adımı olarak değil. Hangi türden olursa olsun, bir ifadenin onu kullananın dil oyunu ve yaşam formundaki kullanılışını açığa çıkarmak, onun meşrûluğu için gereklidir, fakat yeterli değildir. Bundan dolayı, anlam ile kullanımın aynı olduğu biçimindeki katı bir görüşe bağlanmak bir hatadır. $\mathrm{Bu}$ durum, bir kimsenin bir sözcüğün gerçek anlamını, o sözcüğün kullanımını bilmeksizin, mükemmel biçimde bilebileceği, başka birinin de onun anlamını bilmeksizin, kullanımını bilebileceği olgusuyla gösterilebilir. Sözgelimi, birisi "açlık" demek olan Latince "jejunus" sözcügünün anlamını, onu cümle içinde kullanmayı bilmeksizin bilebilirken, "âmin" sözcüğünün nasıl kullanılacağını anlamını bilmeden bilebilir. Kaldı ki bazı sözcükler, anlamı olmaksızın kullanılan sözcüklerdir. 0 halde, kullanım, hiçbir biçimde anlamın hikayesinin tümü değildir; hikâyenin olsa olsa bir bölümünü oluşturabilir, anlamın içerdiği her şeyi tüketemez.(Grayling, 2008, 145-146) 0 halde, yeterli bir gerekçelendirme bütünüyle belli bir yaşam tarzı veya dil oyunu sınırları içinde gerçekleştirilecek bir şey değildir. Kelimeler hayat ve düşüncenin akışı içinde yeni anlamlar kazanabilirler, ancak, bunu aşan bir tarafın da olması gerekir. Eğer bu olmazsa, dil oyunları, açıklama ve izahları bir hayli sınırlandırır, ve onların diğer alanlarla temasını engeller,(Helm, 2000, 106) daha da ilerde, bir tür gayrı-hakikicilik (non-realism) ortaya çıkar. Böylece hem toplumsal olgu ve olaylar, hem de bütün kâinât psiko-sosyal olanla izah edilir; doğaüstü şöyle dursun hâricî herhangi bir yönteme dahi müracaat edilmez. Bu noktada bazı psikolog ve sosyologlar tarafından savunulan şöyle bir varsayım sözkonusu olur: Din sosyal gerçekliklerin bozulmuş yansımasıdır. Tanrı̀nın anlamına ilişsin psikolojik açıklama, kişisel olgu ve olayların içsel hayatın sınırları içinde kalınarak; sosyolojik 
açıklama da toplumsal olgu ve olayların toplumsal sınırların dışına çıkmadan açıklanabileceği varsayımına dayanır. Buna göre, "Tanrı" kavramı psiko-sosyal gerçeklikler yoluyla ortaya çıkar. "Dinî öğretiler, ne Tanrı tarafından ortaya konmuş ne de bilimsel olarak doğrulanmış mantıksal sonuçlardır; aksine, insanların gerçek olmasını candan arzu ettiği psiko-sosyal inançlardır. Yani, onlar insanlığın en eski acil ve güçlü isteklerinin yerine getirilmesidir".(Pals, 2019, 100-101,156) Din en eski sosyal gerçekliktir; zira, bireyler kendi bireyselliklerini aşan ve onları sınırlayan sosyal güçleri dinî bir kisveye büründürmüşlerdir. Din, bu anlamda, fert ve toplum için olsa olsa işlevsel bir güvence, toplumsal gerilimi azaltma ve dayanıșmayı sağlamanın aracıdır. Doğaüstü dünya kurgusal bir dünyadır. Hatta insan da psiko-sosyal linguistik çevrenin bir ürünüdür ve bir bakıma kişisel biyografiler dilsel toplulukların tarihinden bir kesittir. İnsanın tümel bir mâhiyeti yoktur; o, belli bir dilsel topluluk içinde bir mâhiyet kazanır.

Bununla birlikte, eğer teistik bir din (sözgelimi, İslâm) tamamen toplumun ya da bir dil oyununun ürünü olsaydı, tarihsel gerçekleşmelere ve dönüşümlere bu denli etki edemezdi; farklı tarihsel dönemlerde farklı şekillerde ortaya çıkma imkânına asla erişemezdi. Dinî metinlerin anlam alanını belli bir dönemde ve toplumda olup bitenlerin tasviri ve yorumu hatta rivayeti olarak görüp, psikososyal bağlama indirgemek doğru değildir. Toplumsal tarihsel bağlam dinî anlamın anlaşılmasında gerekli olmakla birlikte, metafiziksel ufuk açısından ele alınması gereken boyutları da vardır. Teizme göre, Tanrı̀nın tarihsel olaylara aktif olarak katılımı sözkonusudur. Bundan dolayı, herhangi bir tarihsel olay ne tam anlamıyla tarihsel ne de tam anlamıla metafizikseldir. Sözgelimi, Kur`an`ın kuruluşunda Tanrı etkin olduğu için, o, sırf belli tarihsel hâdiselere atıfta bulunan Arapça bir metin olmasından dolayı topyekûn insan bilincine ve tarihsel-toplumsal şartlara indirgenerek anlaşllamaz.(Tatar, 2009, 30-31)

Şu halde, "Tanrı" ve "gerçek" kavramlarının oluşumunda toplumun etkisinden dolayı, buradan bu kavramların gerçekliğin kendisi olduğu sonucuna varmak yanlış olacaktır. Kavramlar hiçbir zaman atıfta bulundukları gerçeklikle karıştırılmamalıdır. Bir şeyin kavramı o şey değildir. Sözgelimi, "tanrı" kavramı, Tanrı değildir. Bir konu hakkındaki bilginin, o şeyden daha gerçek olduğunu söylemek hayli gülünçtür.(Trigg, 1996, 196)

Anlaşılmaktadır ki, aşkın, yani, dil ve zihin dışı olanı reddetmenin epistemolojik açıdan olumsuz denebilecek başka sonuçları da vardır: Her şeyden önce, burada ortaya çıkan şey bir göreceliliktir. $\mathrm{Bu}$ görecelilik, bazen varoluşun anlamından kuşku duymaya kadar varır. Göreceliliğ̈in doğurduğu önemli sonuçlardan biri, kullanılan epistemik standart ve normlar her ne ise, onların nesnel, tutarlı bir meşrulaştırılmasının olamayacağıdır. Çünkü bu standart ve normların önemi, bütün olarak, özgül bir grup tarafından kabul edilmesinde yatmaktadır. Yani, meşrulaştırma kabul olgusuna dönüşmektedir. İnsanların inandıkları şey, inanma olgusuna göre ikinci sıraya düşmüştür. Özgül bir bakış açısının benimsenmesi karşısında lokal ve ikincil olmaktan ötede olan kesin meşrulaştırma düşüncesi ortadan kaldırılmıștır. O zaman, biz nesnelerin nasıl şeyler oldukları temelinde herhangi bir iddiayı kabul edemeyiz. Şeylerin doğasında içkin olarak bulunan rasyonel ölçütleri kullanarak herhangi bir şey hakkında yargıda bulunamayız. Onlar özgül bir yer ve zamanda ortaya çıkarlar; daha üst bir gerçekliği yansıtmazlar.(Trigg, 1996, 77) Bu durum, insanın kendini tarihin tek fâili olarak görmesinin ve dil ve zihne aşkın olanı reddetmesinin neticesidir. Dahası, insan kendi kendisini hatta Tanrıyı bile bir söylem (dil oyunu) içinde kendisi yaratmaktadır. Çünkü tüm felsefî ve teolojik sistemler, toplumsal ve kişisel gerçeklerin kılık değiştirmiş ve yansıtılmış hâlidir.(Cupitt, 2002, 2425) Oysa, din ve bilim dilinin anlam ve önemi, onların aslında dildışı hakikatin açığa çıkması ya da ifadeye dökülmesinden başka bir şey olmadığı; bir kurguyu veya psikolojik bir alışkanlığı değil, bir ontolojiyi, bir gerçekliği dile getirdiği göz önünde bulundurulduğunda anlaşılabilir. Diğer taraftan, değişik bakış açılarından ortaya konulan görüşlerin doğruluğunu test edebilmek için kullanılabilecek, herhangi bir bakış açısına dayanmayan kıstaslar yoksa, onların doğrulanması olsa olsa ancak pragmatik bir düzeyde olabilir. Pragmatik yaklaşım, dili kullananların tutumları, davranışları ve inançları gibi, biçimselleştirmeye gelmeyen şeyler arasındaki anlamlı ilişkiyi yakalama imkânı vermektedir. Doğrusu, bir cümlenin salt telaffuzu yoluyla söylenenle, belli bir iletişim ortamında anlattı̆̆ı şey arasında yapılan ayırım, anlamın daha başka boyutlarının yakalanması açısından son derece önemli(Koç, 2018, 24) olmakla birlikte, pragmatik yaklaşımı radikal bir şekilde benimseyenlerin, gerçekliğe ilişkin güvenilir tecrübe ya da bilginin olmadığı iddiasına da karşı çıkmak gerekmektedir. 


\section{Değerlendirme ve Sonuç}

Dilin bizatihî bir anlama aracılık etmediği iddiasının insan varoluşu ve entelektüel hayat açısından olumsuz denebilecek neticeleri vardır. Şöyle ki, ne işaret ne de imâ yoluyla dilsel bağlamın dışında atıfta bulunulacak bir gerçeğin var olmadığının iddia edildiği ve dilin kapalı bir yapı olarak görüldüğü dil oyunları kuramına göre, dil ile dildıșı gerçeklik arasındaki bağlantı keyfî ve uzlaşımsal bir sistem ya da koddur. Çünkü ne hâricî dünyanın nesneleri ne de insanî eylemler, kelimenin tam anlamıyla, bağımsız özsel herhangi bir değere sahiptir. Bütün bunlar ve dilsel ögeler, anlamını kapalı devre çalışan bir dil oyunu içindeki yerinden, sistemdeki diğer tüm olanaklı konumlarla farklılığından alır; zira, gösteren ile gösterilen, dil ile dünya arasında hiçbir "doğal" bağlantı bulunmamaktadır. Bu, her çeşit bilişsel iddianın doğruluğunun, gerçekliği kendinden menkul hayat tarzlarında bulunduğunun öne sürüldüğü bir nevi gayrı-hakikîci (non-realist) anlayıştır. Buna göre, gerçeklik dildışı nesnel bir temele dayanmaksızın oluşturulmuş iliş̧kisel ve bağlamsal semantik (dilsel) bir tasarımdır.

Bu durum pek çok kimseye, ilk bakışta ilgici çekici gelmiş olabilir, fakat keşfedilecek gerçek bir şeyin olduğuna inanana kadar, bir etkinlik olarak sözgelimi bilimin geleceği tartışmalı hale gelir. Temellendirilmemiş bilimsel kavram ve uygulamalar, olsa olsa bir yaşam akışının bağımsız nesnel temelden yoksun bir parçası olur. (Trigg, 1996, 70)

Peki, eğer "hakikat" ya da "gerçek" bilgi alanlarından sürgün edilirse, başka neler olur? Şu olur: Filozof ve bilim adamları elde etmeye çalışmalarına rağmen, tecrübe ve bilgiyi birleştirici hiçbir ilke bulunamaz. Bu da, insanın düşünce ve davranışlarının giderek darmadağınık ve uyumsuz bir durum almasıyla sonuçlanır. Bilgi ve öğretimin çeşitli alanları gittikçe daha çok alana ayrılır ve o ölçüde birbirinden bağımsız ve bağlantısız hale gelir. Bilgi ile ilgili dağınıklık ve parçalanmışlık, herkesin sözkonusu ayrıntı yığınının ancak küçük bir kısmını kavrayabilmesine neden olur. Çünkü her bir söylem kendine özgü bir alan oluşturacağı için, kullanılan diller büsbütün farklılaşır ve anlaşmak neredeyse imkânsız hale gelir. Nitekim, insanî davranış düzeyinde, bilginin bu bölük pörçük hale gelmesi toplumda insanların birbiriyle çelişen gayeler uğrunda çalışmalarını intâc eder. Toplumsal doku dağılmaya yüz tutar, ve gittikçe daha çok sayıda altgruplar ortaya çımaya başlar. Her bir grup, kendi birliğini koruyabilmek için daha da dar idealleri seçmek durumunda kalır.(Chittick \& Murata, 2000, 355-356) $\mathrm{Bu}$, ister bilișsel ister kültürel olsun, radikal bir göreceliliktir. Bu, her türden kavramın belli bir hayat tarzı içinde sadece tutum ve inanç belirten kavramlar oldukları anlamına gelir. Eğer bilişsel görecelilik doğru ise (ama "doğru" burada hangi anlamdadır?), o zaman "doğru" ve "bilgi" sözcüklerinin standart biçimde kendilerine atfettiğimiz anlamlara sahip olup olmadıklarını düşünmek de yanlış olacaktır, çünkü yalnızca göreceli doğru, yani, epistemik bir topluluğun tarihinin bir döneminde tasarlandığı şekliyle bir doğru olduğu iddia edilmektedir.(Grayling, 2008, 154)

Bilişsel göreceliliğin "doğru" olduğunu kabul edelim. 0 zaman, diğer hayat şekillerini nasıl "diğer hayat şekilleri" olarak kabul edeceğiz? Bir hayat șeklinin bizimkinden farklı olduğunu belirleyebilmek için, onun var olduğunu ve nelerin onu bizimkinden ayırdığını nesnel dayanaklara göre tespit edebilmemiz gerekmektedir. Fakat eğer diğer hayat şekilleri bizim epistemik erişimimize açık değilse ve diğer insanların tecrübelerini bir hayat şekli olarak yorumlama girişimlerimiz verimsizse, tavsif ve tarif için gerekli verilere ulaşamayız demektir. Eğer biz "öteki hayat şekillerini”nden söz edeceksek, onları nasılsa öylece teşhis edebilir durumda olmalıyız. Başka şekilde söyleyecek olursak, eğer bir hayat şeklinin bizimkinden farklı olduğunu söylüyorsak, bu farklılıkları açık ve seçik olarak ortaya koyabilmemiz gerekir. Bu, sözkonusu hayat şeklini fenomenal ve analitik olarak yeterince yorumlayabilmeye imkân veren bir rasyonalite ile olabilir.

Doğrusu, rasyonalite, varlıkların zâtî idrak edilebilirliğini ortaya çıkarmaktan kültürlerarası ilişkilere kadar, insan zihninin iç işleyişinin ötesine geçen bir ilişkiler ve bağlantılar ağı içinde zuhur eder. Bir şeyin idrak edilebilir olduğunu söylemek, onun anlayabildiğimiz belli bir düzeninin ve yapısının olduğunu söylemek demektir.(Kalın, 2020, 15-16) Var olan şeyleri, onlara anlam ve değer veren bağımsız bir niteliğin zarfı olarak görmenin daha tatmin edici olduğu iddia edilebilir. Buna göre, nesneler ya da eylemler onları aşan gerçek bir özü ve niteliği şu veya bu tarzda paylaşmak suretiyle değer kazanır ve böylece gerçek olur. Bu nitelik, varlıkların tözünde ya da biçiminde içkin olarak bulunur. Varlıklar kendilerinde tözsel olarak bulunan bu içkin nitelik sayesinde aklen kavranır ve dilsel araçlarla ifadeye kavuşturulur. Bu, düşüncelerimizin belli bir hayat tarzı içinde değil, akledilebilirliğin daha geniş bir bağlamı içinde iş görmesiyle mümkün olur. 
Bilim insanları, doğal olgu ve olayları araștırırken onlardaki bu aklî düzeni aramaktadırlar. Sözkonusu düzen ve aklen anlaşılabilirlik olmadan onlar hakkında hiçbir şey bilinemez. Bilim insanları bir şeyi araştırıyor, hakikati keşfediyor ve varsa eğer yanlışları düzeltiyor olduklarına inanma ihtiyacı içindedirler. Eğer şeylerin bir özü ve gerçek nitelikleri yoksa, onların ne olduklarını anlamanın herhangi bir yolu kalmaz. Yani, varlık düzenine içkin nitelikler yoksa, aklîlik ve aklen anlaşılabilirlikten söz edilemez. Zihin ve dilden bağımsız bir ya da birden çok anlaşılabilir gerçeğe epistemik erişim imkânı bulunduğu için, belli bir dönemin önyargı ve varsayımlarının tutsağı olmaktan kurtuluruz. Zihinsel içeriklerimizle onların ne hakkında oldukları arasında kesin bir ayırım yapılmadan entelektüel ilerlemeden bahsedilemez.

Burada şöyle bir paradoksal durum sözkonusudur: Dil oyunları kuramı gerçek mi yoksa o da bir dil oyununun gerçekle bağlantısı sözde olan bir iddiası mıdır? Yani dil oyunları kuramı gerçek bir iddia mıdır? Yoksa, gerçek bir iddia olup olmadığının bir öneminin bulunmadığı gündüz gözüyle görülen rüya kabilinden bir șey midir? Buradaki ironi şudur: Gerçek diye bir şeyin bulunmadığını iddia eden kişinin bile bunu ancak gerçek olarak iddia edebilmesi gerekir. Aksi takdirde, iddia, iddia olmaktan çıkar. Her şey bir dil oyununa dayanır demek, dilin bütünüyle dışına çıkarak, dille dil-dışı karşılık arasındaki irtibata bir yerden bakabileceğimiz ve hakikat dile bağlıdır neticesini çıkarabileceğimiz anlamına gelir. Bunu söylemek, "hakikat mutlaktır" demekten hiç de farklı değildir. Her iki görüş de, dilin dışında, dil ile gerçeklik arasındaki irtibatı inceleyebileceğimiz ve sonra dilin gerçekliği nasıl temsil ettiğini betimleyebileceğimiz, bir bakış açısı veya bir duruş noktasının bulunduğunu zımnen varsayar.

Açıkça anlaşılacağı üzere, farklı dil oyunlarını mukayese etmeyi olanaklı kılacak yeterli ortak bir zemin bulunmak durumundadır. Bu ortak zemin şu iki unsuru içermelidir: İlk olarak, dünyaya ilişkin en azından benzer bazı inançlar olușturmaya imkân veren algısal ve bilișsel kabiliyetlere herkesin ortaklașa sahip olmasını; ikinci olarak, yine onların bu tür inançları biçimlendirmesine imkan veren belli aklî ilkeleri paylaşabilmesini. Çünkü farklılıkları ortaya çıkarmak ancak ontik ve epistemik ortak bir zemine sahip olmakla mümkündür; eğer her şey birbiriyle ilişkisiz olsaydı, bir yaşam biçiminin üyesi, diğer yaşam biçiminin var olduğunu bile tahmin edemezdi. Nitekim, genelleșmiș normal tarzlar olmaksızın ne edebiyat çalışmalarının ne de bireyle ilgili psikoloji ve karşılaștırmalı sosyoloji araştırmalarının yapılması mümkündür. Kaldı ki, başka kültürlerin entelektüel ve pratik hayata ilişkin birikimlerinden faydalanmak nasıl olacaktır?

O halde, farklı dil oyunlarını sosyal hayatın birbirinden kopuk birer görünümü olarak görmek doğru değildir. Her dil oyununun kendi kıstas ve kuralları tarafından yönetildiği ve dışarıdan eleştirilemeyeceği iddiasını kaziye-i muhkeme olarak kabul edecek olursak, bu durumda, astroloji, avuçiçi ve çay yapraklarının okunmasıyla gelecekten haber verme pratiklerinin yanlış ve şüpheli varsayımlara dayandığı açık olmasına rağmen, onlar ayrı yaşam biçimleridir diyerek eleştiremeyecek miyiz? Yine, kabul edilemez sonuçlardan bir diğeri, ayrı bir yaşam biçimi oluşturan siyasî pratikler dıșarıdan eleștirilemez diyerek, Nazizim gibi siyasi yaklașımlar dıșarıdan tenkit edilemeyecek mi? Ayrıca, ahlâkî bakış açısı, belli bir hayat tarzına dayalı olarak temellenen bir bakış olsaydı, o zaman ahlâkî ölçütlerin herkes için geçerli olduğunu ve ahlâkî ilerleme diye bir gerçeğin bulunduğunu söyleyemezdik. İnsan, kapalı bir düşünce sisteminde, yani dil oyunu içinde tutsak kalmak suretiyle, kendi âlem tasavvurunun dışında kalan her şey karşısında körleşir. Felsefî anlamda tehlikeli ve patolojik olan bu durumun önlenebilmesi için tecrübenin yeni unsurları içine alarak genişleyebilecek, dolayısıyla, zenginleșecek bir yapıda tutulması gerekir. Çünkü varlık ve bilgiye dâir tüm iddiaları, kapalı bir tecrübe düzeyine ve aklın belli bir işlevine bağlamak, onları göreceliğe mahkûm etmek olur. Aklın ve dilin tek görevi belli bir hayat tarzını ifadeye kavuşturmak değil; varlık ve varoluşun farklı düzeyleriyle insanı buluşturmaktır.

Nitekim, varlık zuhur ettiğinde, o kendi ışığını yayar ve bir düzen kurar. Akıl, bu sayede hakikati ve mânâyı keşfeder. Aklın keșfin yanında inşa edici fonksiyonu da vardır. Zira mânânın ortaya çıkması ve açık seçik bir doğru haline gelmesi, aklen kavranmasına ve dille ifade edilmesine bağlıdır. Hakikatin mânâsını keșif ve ifade (inșa) eden akıl, ona zihinsel, kavramsal ve dilsel bir biçim kazandırır. Bu "biçim" insanın akıl ve erdeme göre yaşayabilmesi için hayatî bir öneme sahiptir.(Kalın, 2020, 10) Aklın bu iki yönü (keşif ve inşa) birbirinin yerine geçen ve nakzeden değil, birbirini tamamlayan yönlerdir. Biz aklımızın bir yönüyle, șeyler hakkında kavramlar kurar ya da onları kalıplara döküp tahlil ve tasnif eder ve nazarî düzenler geliștirirken; diğer yönüyle, tecrit ve tahlil ederek değil de, cem edip birleştirerek bütüne ulaşmaya çalışırız. Dinî, ilmî, ahlâkî ve bedî̂ 
hakikatler aklın her iki gücü kullanılarak, yeri geldiğinde nazarî yolla, yeri geldiğinde varoluşsalfenomenolojik yolla yorumlanmalıdır. Çünkü kâinât çok katlı ve çok boyutlu çeşitli varlık mertebelerinden oluşmakta ve kâinattaki her şey, kozmik bir bütünlük içinde birbiriyle ilişki içindedir. Bu bakımdan, her varlık mertebesinin tabiatına uygun olarak, onu anlamayı ve yorumlamayı mümkün kılan farklı anlama ve yorumlama yöntemleri ve ıstılahlar kullanılmalı; tek bir bilişsel yöntemle yetinilmemelidir. Yeri geldiğinde, dil ve mantık düzeyindeki tahlillere (mantıkî düzen), yeri geldiğinde fenomenolojik ve varoluşsal yorumlara (hikmet düzeni) ve yeri geldiğinde âlem hakkındaki bilimsel genellemelere (tecrübî düzen) müracaat etmelidir.(Kuvancı, 2016, 138)

Öyle anlaşllyyor ki, bütüncül düşünme tarzı deneysel veya rasyonalist, tarihsel veya sistematik, apodiktik (açık seçik mantıksal delillere dayanan) veya pedagojik, analitik veya betimleyici değildir. Aynı anda bunların hepsi ve hiç biridir. Kavramsal analizi ahlâkî yargıyla, deneysel gözlemi manevî tecrübeyle, tarihsel eskatolojik (uhrevî) anlatıyı beklentiyle ve soyut düşünceyi emir ve yasaklarla birleștirmek gerekmektedir. Çünkü bir boşlukta ortaya çıkmamış olan kavramlar, gerçekliğin farklı yönlerine karşllık gelirler. Işığı görür, gülü koklar, kirazı tadar, boyutu algılar, sonsuzluğu düşünür, bir şey ile gölgesini birbirinden ayırır, bir emri anlar, bir çağrıya cevap verir, hayatın anlamını tefekkür ederiz. Tüm bu epistemik eylemler, dünyayı anladığımız zihinsel ve kavramsal yeteneklerimiz hakkında bir şeyler söyler. Dahası bunlar, dışımızdaki şeylere karşılık gelirler ve kendi öznelliğimizin ötesine geçerek ufkumuzu genişletirler. Akıl yoluyla düşünme, zihnimizde birtakım kavramları evirip çevirmek değil, hakikatini bize her an takdim eden varlığın huzurunda durmayı ve onunla akıl ve erdeme dayalı bir ilişkiye geçmeyi ifade eder.(Kalın, 2020, 47,63)

Nitekim, gerçeğin anlam alanı onun farklı entelektüel kabiliyetlerle sürekli yorumlanma imkânına sahip olması sayesinde genişler. Varlığın çok katmanlı yapısını ancak zengin terminolojiye dayanan, çok boyutlu bir düşünme biçimi ile idrak edebiliriz. Bilme eylemimize konu olan şeyle bilme aracımız arasındaki uygunluk, epistemik iddialarımızın doğruluk derecesini belirler. Tüm kavram ve yöntemlerin amacı, varlı̆̆ı bütün olarak kavramamızı sağlamaktır. Sözgelimi, mistik söylem ile rasyonel söylem, birbirini derinleştirip genişletebilir. Hatta bunlardan biri diğeri olmadan anlaşılamaz. Teorik akıl, kavramlar arasında ilişki kurar, önermeleri tahlil eder, kıyaslar yapar ve onların işaret ettiği neticeleri çıkarır. Temel önermeler bilinirse, onlardan çıkarılabilecek mantıksal sonuçlar da teorik olarak takip edilebilir. Fakat mistik söylem, gerçeği çözümleyerek değil de bütünlüğü içinde ifade etmek ister. Mantıksal olarak bakıldığında, şayet bir mistik söylemin anlamı, kavramlar ya da dil aracılığıyla bir şekilde yeniden üretilebilseydi, zaten o, mistik söylem olmaktan çıkar ve bir tür nazarî-kavramsal bir söyleme dönüşürdü. Daha açık bir ifadeyle, kavramlarla yeniden ifade edilebilir olan söylem, mistik olmazdı. Bu yüzden tüm söylemler, temel özellikleri nasılsa öyle var olmaya devam etmelidir. Çünkü birinin ifade etmekte veya dilde üretmekte yetersiz kaldığı gerçekleri bir diğeri açığa çıkarabilir. Bu bakımdan bir söylemi merkeze koyarak ya da diğerinin yerine ikame ederek ötekileri büsbütün ona göre yargllamak uygun değilse, bunlardan her birini birbirinden kopuk olarak görmek de uygun değildir.

Sonuç olarak, her bir dil oyununu varlığın ve varoluşun bir boyutunu ifade etmenin birbirini tamamlayan aracı olarak görmek daha doğrudur. Öyleyse bir dil oyununa angaje olmak bizi diğerlerini yok saymaya götürmemelidir. Anlama ve açıklamanın farklı düzeyleri vardır. Dil de, anlamın kavranabilmesi için aslında yeterli değildir, ve anlama olayı asla zihinsel anlama veya kavrama ile sınırlanamaz. Aklın hem analitik hem de sezgisel işlevleri vardır. İnsan, mantıksal tahlil ve sezgisel idrak kabiliyetlerini birbiriyle çelişmeyecek şekilde kullanabilir ve ahlâkî tercihleri şekillendirebilir. Zaten böyle bir ayırımın, açı konuşmak gerekirse, belli bir konuya derinlemesine nüfuz etmek, o konunun başka alanlarla olan ilişkisini gözden kaçırmadan, sağlıklı ve güvenilir sonuçlara ulaşmak için bilgi düzeyinde yapılmış, büyük ölçüde zihnî bir ayırım olduğunu unutmamak gerekir. $\mathrm{Bu}$ yüzden, bilişsel kabiliyetler ve buna bağlı ortaya çıkan söylemler arasındaki sınıflandırmaların, bir anlamda geçici, sunî bir sınıflandırma olduğunu kabul etmek durumundayız. Zira, eğer bu bakış açlları sonunda bir yerde buluşup bütünlük arz etmezse; fert, toplum, kültür ve son derece karmaşık olaylar sahnesi olan tarih açısından vahim sonuçlar doğurabilecek yanlışlıklara yol açılmış olur. Aklın farklı işlevleri birbirini tamamladığı gibi farklı bakışaçıları (yani, dil oyunları) da birbirini tamamlar ve bütüncül bir yaklaşımı gerektiren gerçekliğin çok katlı yapısını ortaya çıkarmamıza yardımcı olur.(Aydın, 1986, 10; Kalın, 2020, 35-36) Analitik dil ile ifade edilemeyen bir şeyin anlamı, başka bir ortamda, sözgelimi, müzik eserinde açı̆̆a çıkabilir. Dilde kaybettiğimiz bir şeyi müzik alanı içinde bulabiliriz. Başka bir ifadeyle, dilsel yolla ifade edilemeyen anlamlar müzikal 
eserler vasıtasıyla aktarılabilirler; zira, mantıkî kavramları kullanmadan onları aktarmanın imkânı bulunmaktadır. Bu da göstermektedir ki, salt dilsel ifade araçlarından farklı ifade araçları da vardır. Her bir ifade aracı gerçekliğin bir seviyesinden diğer seviyesine, bir anlama düzeyinden başka bir anlama düzeyine götürür. Bu geçişin olabilmesi için ifade yol ve yordamının, șeylerin varlık tarzıyla gerçekten uyumlu olması șarttır. Bundan dolayı, hakikate erme konusunda salt zihni tefekkürün en geniş, en kestirme yol olduğunu söyleyemeyiz. Burada en iyisi kafa ile gönlü ya da farklı dil oyunlarını bir yerde buluşturmaktır. $\mathrm{Bu}$, insan olarak bizim, parçalanmaktan kurtulup bütünlüğümüzü korumamız açısından da önemlidir.

\section{Kaynakça}

Acar, R. (2013). Teolojik Dilin Husûsiyeti ve Ateist Argümanların Sinırı. Pasifik Ofset.

Aydın, M. (1986). İslâm`ın Estetik Görüşü. Kubbealtı Akademi Mecmuası, 4, 9-25.

Bakar, 0. (2012). İslâm Bilim Tarihi ve Felsefesi (I. Yanar, Çev.). İnsan Yayınları.

Barret, C. (1991). Wittgenstein on Ethics and Religious Belief. Blackwell.

Barthes, R. (1977). Elements of Semiology (A. Lavers \& C. Smith, Çev.). Hill and Wang.

Chittick, W. C., \& Murata, (2000). İslâm ın Vizyonu (T. Koç, Çev.). İnsan Yayınları.

Cupitt, D. (2002). Is Nothing Sacred?: The Non-Realist Philosophy of Religion. Fordham University Pre

Dancy, J. (2006). Introduction to Contemporary Epistemology. Blackwell Publishing.

Falzon, C. (2001). Foucault ve Sosyal Diyalog (A. Cevizci, Çev.). Paradigma Yayınları.

Gazzalî, E. H. (1964). Mişkâtü l-Envâr (E. alâ Afifî, Ed.). El-Dârül- Kavmiyyeti li’ Tıbâtî ve`n-Neşri.

Grayling, A. C. (2008). Wittgenstein (M. Yllmaz, Çev.). Altın Kitaplar.

Helm, P. (2000). Wittgenstein Religion and 'Reformed' Epistemology. İçinde R. L. Arrington \& M. Addis (Ed.), Wittgenstein and Philosophy of Religion (101-118). Routledge.

Janik, A., \& Toulmin, (2008). Wittgenstein ’n Viyanası (A. Cevizci, Çev.). Paradigma Yayınları.

Kalın, İ. (2020). Perde ve Mânâ: Akıl Üzerine Bir Tahlil. İnsan Yayınları.

Kerr, F. (1997). Theology after Wittgenstein. SPCK.

Koç, T. (1995). Din Dili. Rey Yayıncılık.

Koç, T. (2018). Dilin Ötesi: Kur`an`ın Dil ve Uslübu Üzerine. İz Yayıncllık.

Kuvancı, C. (2016). Gazzâlîyye Göre Din Dili. İlahiyat.

Livingston, R. (1998). Geleneksel Edebiyat Teorisi (N. Özdemiroğlu, Çev.). İnsan Yayınları.

Lyotard, J.-F. (2014). Postmodern Durum (ì. Birkan, Çev.). BilgeSu Yayıncllık.

Magee, B. (2000). Büyük Filozoflar: Platon`dan Wittgenstein'a Batı Felsefesi (A. Cevizci, Çev.). Paradigma Yayınları.

Malcolm, N. (1993). The Groundlessness of Belief. İçinde L. Pojman (Ed.), Philosophy of Religion: An Antology ( 461-469). Wadsworth Publishing Company.

McGinn, M. (2005). Wittgenstein and the Philosphical Investigation Routledge.

Mevlânâ. (2000). Mesnevî-i Şerif (Â. Çelebioğlu, Çev.; C. 1). Millî Eğitim Bakanlığı Yayınları.

Nielson, K. (1982). An Introduction to the Philosophy of Religion. The Macmillan Press Ltd.

Pals, D. E. (2019). 9 Din Kuramı (M. Ulu, A. Özbolat, Ö. Akdağ, R. Adıbelli, A. Taştan, M. D. Dereli, N. Karslı, \& Ö. F. Darende, Çev.). Kimlik Yayınları.

Rorty, R. (1979). Philosophy and the Mirror of Nature. Princeton University Pre 
Scruton, R. (1981). From Descartes to Wittgenstein: A Short History of Modern Philosophy. Routledge \& Kegan Paul.

Tarnas, R. (2012). Batı Düşüncesi Tarihi: Modernite`den Günümüze Kadar (Y. Kaplan, Çev.; C. 2). Külliyat Yayınları.

Tatar, B. (2009). İslam Düşüncesine Giriş. Değer Eğitim Merkezi Yayınları.

Trigg, R. (1996). Akılcılık ve Bilim: Bilim Her Şeyi Açıklayabilir Mi? (K. Yerci, Çev.). Sarmal Yayınevi.

Wittgenstein, L. (1958). Philosophical Investigations (G. E. M. Anscombe, Çev.). Prentice Hall.

Wittgenstein, L. (1969). On Certainty (G. E. M. Anscombe \& G. H. von Wright, Ed.; D. Paul \& G. E. M. Anscombe, Çev.). j. \& J. Harper Edition

Wittgenstein, L. (1970). Lectures \& Conversations on Aesthetics, Psychology and Religious Belief (C. Barret, Ed.). Basil Blackwell.

Wittgenstein, L. (1978). Philsophical Grammar (R. Rhees, Ed.; A. Kenny, Çev.). University of California Pre

Wittgenstein, L. (1990). Philosophical Remarks (R. Hargreaves \& R. White, Çev.). Basil Blackwell.

Wittgenstein, L. (1998). Zettel (G. E. M. Anscombe \& G. H. von Wright, Ed.; G. E. M. Anscombe, Çev.). Basil Blackwell.

Wittgenstein, L. (1999). Yan Değiniler (O. Aruoba, Çev.). Altıkırkbeş Yayınları.

\section{Extended Abstract}

According to the language games theory, all representational systems (id est all discourses), whether scientific or religious, are nothing more than inter-human conventions that take place within the limits of practical life. The idea that the fields such as science, religion, art, and morality have objective criteria of truth and validity should be abandoned. Therefore, the criteria of rationality, meaningfulness and accuracy relating to the concepts and statements in a discourse should be sought within the discourse itself in question, because there is no reality that is independent of cultural-linguistic categories and is not related to any language game. The concept of "truth" is a concept that has meaning only in the context of any language game. So that a word and a concept have a meaning it is not necessary to be an essence or an objective correlative to what they indicate. Moreover, the properties that are claimed to constitute the essence of something are produced within a certain language game. For example, when we look at the words "good" in morality and "beautiful" in art, we tend to think that there is an essence of goodness and beauty that those imply and indicate. However, the thinkers who adopt the language games theory say that these words have no essence and that a so-called "semantic" essence can be revealed only by looking at their actual usage.

What happens if the "truth" or "real" is banished from the fields of knowledge? Although philosophers and scientists try to obtain it, no principle that unifies experience and knowledge can be found. This causes people s thoughts and behavior to become increasingly disheveled and incompatible. The various fields of knowledge and teaching are increasingly divided into more areas and to that extent those becomes independent and disconnected from each other. The clutter and fragmentation related to knowledge causes anyone to grasp only a small part of this pile of detail Because each discourse creates a unique field, the languages differ altogether, and communication becomes almost impossible. As a matter of fact, at the level of human behavior, this fragmentation of knowledge makes people work for contradictory goals in society. The social fabric tends to disintegrate, more subgroups begin increasingly to emerge. Each group has to choose even narrower ideals in order to maintain its unity. This is a radical relativity, whether cognitive or cultural. This means that all kinds of concepts are simply the concepts that express attitude and belief in a particular lifestyle. If cognitive relativism is true (but in what sense is "true" here?) then it would also be wrong to consider whether the words "true" and "knowledge" have the meanings we ascribe to them in the standard way; for it is claimed to be only a relative truth, that is, a truth as it was conceived at some time in the history of an epistemic community. This is a kind of non-realist understanding in which truth of all kinds of cognitive claims is claimed to be found in self-evident lifestyle 
Kuvancı, C., “Dil Oyunları Kuramı Ne Önermektedir?” ODÜSOBİAD 11(2), 2021, 377- 390, Doi: 10.48146/ $390 \cdot$ odusobiad. 858756 